\title{
Unfaithful translation and translation purposes: The Discovery of America by Joachim Heinrich Campe, in Romanian version ${ }^{\dagger}$
}

\author{
Iulia Elena Zup ${ }^{\mathbb{A} \mathbb{R}^{\natural} \star}$ \\ Faculty of Law, "Alexandru Ioan Cuza" University, Bd. Carol I 11, 700506 Iași, Romania
}

\section{Article info}

History:

Received August 6, 2021

Accepted August 14, 2021

Published August 18, 2021

Key words:

translation

old literature

comparative analysis

glosses

\begin{abstract}
This paper investigates the purpose of using certain translation strategies in the Romanian version of the novel Die Entdekkung von Amerika (1781) by Joachim Heinrich Campe, translated from German by the merchant and teacher Nicola Nicolau from Braşov and published at the Printing House of the University of Buda in 1816 with the title Descoperirea Americii. Starting from the skopus theory developed by Hans Vermeer, the purposes of producing the Romanian version are analysed, in comparison with those of writing the original text and of the translations in other languages. At the textual level, through the comparative analysis, strategies are highlighted, especially omissions and interpolations, which help to achieve the goals of the translator or the text. Thus, through the transfer between the source and the target culture, one can observe the maintenance of the pedagogical Enlightenment goals, of instructing the masses regarding moral virtues and historical and geographical knowledge, and the addition of the one of cultivating the Romanian language.
\end{abstract}

\section{Introduction. The skopus of the translation and the translator}

In 1978, the German linguist Hans Josef Vermeer stated in the magazine "Lebende Sprachen" the skopus theory ('Skopostheorie'), according to which translation strategies are determined by a certain purpose, a certain intentionality of the translational action. Thus, the translation has a communicative purpose in the context in which it is received by the target audience, the source text being an opportunity to provide information to the receiving culture. Depending on the reader and the context of the reception, purposes of the text are maintained, altered or introduced by producing the translation. The translational action is an intentional one, the translation representing text production in a certain target context, for certain purposes and for readers who will read it in certain circumstances (Vermeer, 1978). Thus, the skopus theory detaches itself from and goes beyond a static linguistic analysis in which the emphasis is put on identifying equivalences, errors, the fidelity of translation, all of which are now analysed as means of achieving the goals - of the source text, of the target text, of reading. Through their action, the translators-cultural mediators - can benefit from freedom in maintaining the purposes of the text or in adding others, but this freedom also brings with it a certain degree of responsibility (Agori, 2005). From this perspective, they occupy a central position in the process of cultural transfer.

Delisle \& Woodsworth (1995), also highlighted the pivot role of the translator, who was portrayed as one of the factors responsible for cultural evolution, who contribute decisively to the development of national languages and literatures. Even-Zohar (1990, p. 53) identifies the translator as one of the essential factors of cultural interference. New theories focus on the dynamic processes which occur in both directions of the cultural transfer, on the intersections of societies and cultures, namely 'histoire croisée' (Werner \& Zimmermann, 2006), a cultural phenomenon to which the translational action is part.

\footnotetext{
${ }^{\dagger}$ This work was supported by a grant of the Ministry of Research, Innovation and Digitization, CNCS/CCCDI UEFISCDI, project number PN-III-P1-1.1-TE-2019-0721 within PNCDI III.

^Email address: iuliazup@gmail.com.
} 
The age during which translation and the translator played undoubtedly an essential role for the cultural transfer and the development of the Romanian language and literature is the Enlightenment (the second half of the $18^{\text {th }}$ century and the beginning of the $19^{\text {th }}$ century), in which more secular texts were translated from modern languages (German, Italian, French), unlike in the previous period, when translations of religious texts from Greek and Slavonic, or from Latin (in the Romanian provinces that were part of the Habsburg Empire) predominated (Gheție, 1982, p. 77-78). The interest for secular texts represents on the one hand a detachment of culture and science from the church, and on the other hand a first stage of the modernization of the Romanian language (Gheție, 1982, p. 65), through the flow of new (specialized) vocabulary, introduced through translations.

In this context, the novel Die Endekkung von Amerika by the German pedagogue Joachim Heinrich Campe was translated into Romanian by the Romanian merchant Nicola Nicolau. The text, analysed in this article, poses interest because, by exporing the goals pursued by the author and translators, including the Romanian one, one can observe the circulation of the ideas of the Enlightenment in Europe. The goals are achieved at the textual level both declaratively, in the foreword or afterword, narrative through the discourse, and at the translational level, through the means available to the translator. Thus, this paper aims to investigate from a new perspective a text that has entered the focus of valuable recent research, of the team led by Gînsac (2017) in the project Practici de traducere a numelor proprii in scrisul românesc premodern: 1780-1830, cwhich focuses on the translations of proper names in this work, and of Tatay (2011), who deals with the metal engravings, from the volume in Romanian.

\section{Die Entdekkung von Amerika}

In 1781, Die Entdekkung von Amerika. Ein angenehmes und nüzliches Lesebuch für Kinder und junge Leute, was published in Hamburg, a series of three volumes that shows the discovery of the New World: the first volume about Columbus, the second about Cortes and the third about Pizarro. The first 18 stories out of a total of 20 of the first volume, Kolumbus oder die Entdekkung von Westindien were translated into Romanian. The German author, Joachim Heinrich Campe (1746-1818), was a theologian, linguist, enlightened pedagogue, author of children's books and tutor of the Humboldt brothers. He was one of the most important representatives of the educational movement called philanthropinism (Blamires, 2009, p. 23), along with Johann Bernhard Basedow, Christian Gottfhilf Salzmann and Eberhard von Rochow; its main activity was writing children's books for pedagogical purposes. The purpose of writing such volumes was the moral education, which could be achieved most easily, in the vision of philanthropinism, through stories. The German didactic works follow the model of the French Enlightenment youth literature, structured in the form of didactic conversations in a family context: Emilé sau despre educație (1762) by Jean-Jaques Rousseau; Magasin des Enfants (1756) by Jeanne-Marie Le Prince de Beaumont; Conversations d'Emilie (1774) by Louise d'Epinay; Entretiens, drames et contes moraux, a l'usage des enfans (1778) by Marie-Elisabeth de la Fite. The method of education proposed by the Enlightenment pedagogical literature was Socratic, the child's curiosity, manifested in the novel in the form of questions, guided the learning process. The works show that human behaviour can have consequences, good or bad (Dietz, 2019, p. 204). Among the works of the philanthropinist movement, Campe's novels were the most successful, appearing in countless editions and being translated into many languages. By the time he published Die Entdekkung von Amerika, Campe was already famous for his novel Robinson der Jüngere (1779), an adaptation of Defoe's work for children, which was also translated into Romanian in 1817 and 1835. The popularity of Campe's works in the Romanian-speaking territories is clear from the fact that four of his works were translated (Camară, 2017, p. 25): Descoperirea Americii; Theophran sau Iscusitul sfatuitor pentru neiscusita tinerime (Buda, 1833), translation by Ioan Theodorovici of Theophran oder der erfahrene Rathgeber für die unerfahrene Jugend (1783); Robinson Cruzoe seau Intämplärile cele minunate a unui tânăr, translation by Vasiel Drăghici (Iași, 1817 and 1835) of Robinson der Jüngere; Cărticica invățăturilor morale pentru copii de școală, translation by Gheorghe Lazăr of Sittenbüchel für 


\section{Schulkinder.}

The Discovery of America becomes a bestseller of those times as well, appearing in countless editions and being republished many times in German ${ }^{1}$. In the foreword, dated 1781 and entitled Von der Absicht dieses Buchs [On the intention of this book], Campe states that one of the purposes of publishing the text is to make up for the lack of books for children and youth, and considers that the natural continuation of his previous volumes, Kleine Kinderbibliothek [Children's Library] and Robinson, is The Discovery of America, in the sense of a progression of style and information transmitted. Thus, the young reader receives an enlightened education, on the one hand by the flow of historical and geographical data, on the other hand by promoting moral virtues - even by showing the true human nature, in its complexity, by offering models or anti-models throughout the novel, by indicating the correct conduct towards other human beings. Unlike previous works, written for younger children, the story is less often interrupted by dialogue, because teenagers do not need so much clarification. Campe's interest in popularizing the science of history is also evident in the publication of other historical or travel works, the titles of which show his purpose of enlightening the masses and spreading knowledge ${ }^{2}$. In recounting the events of The Discovery of America, Campe draws on historical writings, and when he comes across conflicting information, he presents William Robertson's point of view. In 1777, the Scottish historian Robertson published The History of America in three volumes - a work of the European Enlightenment, which had been translated into German by Johann Friedrich Schiller in the same year of its publication and published in Leipzig (Geschichte von Amerika). This work enjoyed great success in Europe, appearing in several editions and being translated also into Italian, Spanish, Dutch and French. Probably also from Robertson, Campe takes the idea of highlighting the qualities of Native Americans, thus contradicting other historians, who had asserted their degenerative character (Buffon, de Pauw), and advocates tolerance (Petroff, 2017, p. 3). Despite the desire to tell the historical truth, Campe admits that he had to soften certain descriptions of the human character, given the target reader. Also in the foreword, Campe shows that in the year of its publication, the volume was already translated in Paris, by Junker, since in France there was also a lack of the genre youth literature.

\section{The translations into other languages}

The volume is so successful that, shortly after its publication in Germany, it is translated into several European languages and even published in several editions. It should be noted that translators are also enlightened scholars and propagators of the ideas of the Enlightenment in their country. The French translator, Georges Adam Junker, mentioned by Campe in the foreword, had also translated Robinson der Jüngere and Lessing's works into French, as well as some historical works ${ }^{3}$. However, his enlightened

\footnotetext{
${ }^{1}$ Until 1816, the year when it was published in Romanian, it appears in the editions or is republished: 1781 - Tübingen: Frank und Schramm; Hamburg: Bohn; 1782 - Tübingen: Frank und Schramm; Tübingen: Frank und Balz; Hamburg: Bohn, an edition which also contains an image, representing Columbus stepping for the first time on the New World, with the translation of its title into French; 1783 - Tübingen; Frank und Schramm; 1784 - Straßburg: P.J. Dannbach, with the translation of the first page into French, the editor's foreword in French and the mentioning that the same characters from Robinson were maintained: Johann, Gottlieb, Fritz, Hans, Lotte, Christel; Leipzig: Lauffer; 1785 - Tübingen: Frank und Schramm; 1790/1 - Braunschweig; 1794 - Braunschweig: In der Schul-buchhandlung; 1796 - Braunschweig: Schulbuchhandlung; 1798 Tübingen: Balz und Schramm; 1800 - Reuttlingen: J.J. Fleischhauer; 1801 - Braunschweig: in der Schulbuchhandl; 1804 Altona: Bechtold; 1807 - Braunschweig: Schulbuchhandlung; 1808 - Reuttlingen Joh. Jak. Fleischhauer; 1810 - Viena: B. Bauer; 1813 - Viena: Bauer, which contains a metal engraving by von Friedrich Weber; 1814 - Reutlingen: Fleischhauer \& Bohm; 1815 - Reutlingen: in der J.J. Mäcken'schen Buchhandlung. A bilingual edition, in German and English, is published with the purpose of helping German children learn English: 1808, Oldenburg Schulze: The discovery of America for the use of children and young persons; ein Lesebuch für Anfänger in der englischen Sprache, nebst einem Wortregister mit beygefügter Aussprache, auf die in England selbst übliche Weise bezeichnet.

${ }^{2}$ Philosophische Gespräche über die unmittelbare Bekanntmachung der Religion und über einige unzulängliche Beweisarten derselben (Berlin, 1773), Erste Sammlung merkwürdiger Reisebeschreibungen für die Jugend (Hamburg, 1785-1793; Braunschweig, 1794-1801), Geschichte der französischen Staatsumwälzung (Frankfurt/Leipzig, 1792).

${ }^{3}$ Pensées libres sur différentes parties de l'art de la guerre (Paris, 1800).
} 
spirit is especially evident in his author's books: on German linguistics, on German theatre, textbooks on German language and literature. The French translation, in turn, enjoyed an active reception, being published in several editions (Hamburg, 1782, La Découverte de l'Amérique pour l'Instruction et l'Amusement des Enfans et des jeunes Gens, cu noi ediții în 1784, 1798, 1803, 1817), new translations and editions in 1785, 1797, 1810, 1827, 1836, 1838, 1845.

The English translator (Columbus or The discovery of America: as related by a father to his children, and designed for the instruction of youth, Sampson Low, London, 1799 ${ }^{4}$, with new editions in 1811 and 1828) is Elizabeth Helme (1772-1813), a school principal in Brentford and a successful author. Among her works are numerous didactic-historical youth novels, also written in the form of dialogue, such as Maternal instruction or Family conversations on moral and entertaining subjects: interspersed with history, biography, and original stories: designed for the perusal of youth (1804), The history of Rome: from the foundation of the city to the fall of the eastern empire, related in familiar conversations, by a father to his children (1808) or The history of England: related in familiar conversations, by a father to his children (1834). At the end of the $18^{\text {th }}$ century, in the United Kingdom, the translation of texts was indeed a practice that provided additional income, but it can be seen from the titles above that Helme adopted the didactic Enlightenment style, considered in those days to be appropriate for female writing.

We have more information about the Hebrew and Yiddish versions due to the research of Shavit (1993, 1995), these translations being all the more relevant for the purposes of this paper as, like the Romanian translation, the text is modified and adapted to match the requirements of the receiving culture. According to Shavit (1995), the text was chosen to be translated into Hebrew, as it could be easily transformed so that it could be presented as a historical-geographical text, because fictional texts, even translations, did not correspond to the Jewish canon of those times. The narrative element of the frame in dialogue form, characteristic for the philanthropinist movement, is removed, and the events are narrated from an authorial perspective. This modification of the source text would correspond to the translation norms of the Judaic-Jewish system, of a cultural approach to the original text, the practice of translation being seen in Jewish culture as a creative activity, which follows its own laws. Thus, the status of the practice of translation did not differ much from the practice of producing original texts (Shavit, 1993, p. 757). The purpose of the translation is, however, also in this case, to illuminate the masses and broaden the historical horizons: "Translating Campe was not perceived of in terms of writing fictional narratives, nor in terms of mere adventure stories about the discovery of America or any such wonderful journey, but in terms of creating a repertoire of historical awareness and creating tools for implementing a new and enlightened Weltanschauung" (Shavit, 1995, p. 78). The first translation into Hebrew dates from 1807 (Altona), the translator Moshe Mendelssohn-Frankfurt transformed Campe's work into a historicalgeographical account. Campe's name is not mentioned on the cover or front page, but the translator states in the preface: "[the volume] was written, gathered and composed in Hebrew from popular books, in a clear and simple language, to teach the people of Israel about the beauty of this language and the works and miracles of God, which he performs everywhere." The omission of the author's name on the cover or the first page would not have represented disrespect or an attempt at plagiarism, because, in the introduction, the translator Mendelssohn expresses his appreciation for Campe, which he characterizes as "intelligent, enlightened and sincere" (Shavit, 1993, p. 758). The translator adds, compared to the aims stated by Campe in the foreword of 1781, two more. The first would be to show the beauty of the Hebrew language, in competition with Yiddish and other European languages, of the countries where the Jewish communities lived, and thus the cultivation of the Jewish language and identity - a goal stated also in the afterword of the Romanian translation regarding the Romanian language. The second goal is to teach the youth about the greatness of God, which is a change in the purpose stated by Campe, namely moral teaching, but not necessarily religious. This religious purpose is also meant to cultivate Jewish identity. The

\footnotetext{
${ }^{4}$ English translations of Die Entdekkung von Amerika are published in the same year in London, at a different publishing house - J. Johnson, and in Dublin in 1800.

${ }^{5}$ The English translation was made by the author of this article, after the translation into German by Shavit (1993, p. 757).
} 
translation of Hirsch Baer Hurwitz, also known as Hermann Bernard, a Jew living in Russia, dates from 1810. According to Shavit, the text is translated again into Hebrew, only three years after Mendelssohn's translation, because the latter was not known in Russia or was difficult to obtain. Since the translator belongs to the first generation of maskils ${ }^{6}$ in Russia, the text is considered the first important achievement for the Russian Jewish maskils - or Haskalah, the Jewish Enlightenment, intellectual movement of the late $18^{\text {th }}$ century, which advocated the adoption of the ideas of the Enlightenment. Campe's text was very popular among Haskalah writers, with Jewish maskils beginning their careers as writers by translating this book, despite the fact that there existed already many editions (Shavit, 1995, p. 77). Other variations that emphasize the historical content are the translation of Mendel Lefin (Liov, 1818) and of Mohr (Liov, 1846) (Shavit, 1993, p. 759).

The Hebrew translation was so popular that the Jewish community, scattered throughout Europe, came to know the historical facts about the discovery of America, a fact which would have contributed, at a later stage, to a fascination with the New World and even to the emigration there (Völpel \& Shavit, 2002). In 1817, the text was also translated into Yiddish by Chaikel Hurwitz, one of the initiators of the Hebrew Enlightenment. It was not until 1823 (Vilnius) that the full version was translated into Yiddish.

The Greek translation (1820), made by Ioannis Billiaros and revised by Giorgios Russiadis - a linguist who publishes several works on Greek linguistics in German, was used in schools and is also an unfaithful translation, because, instead of the father, the narrator is a pedagogue responsible for the education of several children (Polioudakis, 2008, p. 170-171). The German names are replaced by Greek names. The volume is also translated into Danish (1813), Polish (1809), Dutch (1782-1783), Portuguese (1836), Swedish (1813-1814), Spanish (1803), Slovak (1840), Hungarian (1783).

\section{The translation into Romanian}

At the time when the Romanian translation is published, in the Romanian-speaking territories circulated the Hebrew and Yiddish versions in the Jewish communities ${ }^{7}$ and the Hungarian version ${ }^{8}$, published in Cluj-Napoca in 1783. The Hungarian translator is the Cluj linguist Sámuel Gyarmathi (1751-1830), author of a highly acclaimed work on the comparative history of the Finno-Ugric languages - Affinitas lingua hungarice cum linguisfennice originis grammatice demonstrata (Göttingen, 1799), the first scientific demonstration that Hungarian belongs to the Finno-Ugric family, and of the first Hungarian etymological dictionary, Vocabularium (Viena, 1816), which compares the Hungarian vocabulary with 57 other languages, including Romanian.

The Romanian translation is made by Nicola Nicolau (1762-1837), who came from an old and wealthy family of merchants from Brașov (Iorga, 1931, p. 75), the taste for literary works being fuelled by his travels through Europe, for commercial purposes. Due to financial difficulties, he accepts a job as a teacher at the school in Șcheii Braşovului (1828-1829), and in 1830 he is appointed principal of the school founded by Dinicu Golescu in Wallachia (Mureșianu, 1931). Along with Ioan Piuariu-Molnar and Gavril Onișor, he is a member of the "Soțietății filosoficești a neamului românesc în Mare Prințipatul Ardealului" [The Philosophical Society of the Romanian Nation in the Great Principality of Transylvania], an encyclopædic and Voltairean society, founded in 1795, with the purpose to cultivate the Romanian language and culture, and which was in contact with scholars from Wallachia, such as Enache Văcărescu (Pop, 1946, p. 6). The society's program included the publication of a journal, for which no approval was received from Vienna, and which would have covered topics from various fields (theology, geography, history, physics, mathematics, philosophy, pharmacy, nutrition), thus representing the first initiative to make the sciences

\footnotetext{
${ }^{6}$ The word maskil designates a Jewish autodidact scholar, who lived in a Slavic country and could speak a living language (usually German).

7 “Columbus was written so beautifully that it could be read and understood everywhere - in Russia, Poland, Galicia and Romania, every place where Jews were to be found." (A. B. Gottlober, Memories and Travels (2), Jerusalem, 1976, p. 15-17, apud Shavit, 1995, p. 78).

${ }^{8}$ Amérikának fel-találásáról: a gyermekek és az ifjak kedvekért.
} 
popular (Pop, 1946, p. 6). Among the books mentioned in the society's program was a geography work, which, according to Iorga, would be in fact the one published by Nicolau (Bordaș, 2006, p. 78) in 1814 at the Printing House of the University of Buda, under the title Gheografia sau Scrierea Pământului, întocmită dupăorînduiala cea mai noao, așezatăpentru 4părțiale Pămîntului, adecă: Europa, Asia, Africa, America cu tot cuprinsul lor. This text represents a rewriting of Geografia by Amfilohie Hotiniul, from 1795, translated after Claude Buffier, to which Nicolau adds other data, collected on the occasion of his many trips in the interest of business. Nicolau's interest in the New World is obvious from this work, because it includes in volume II two chapters on this topic: the first about Cotez Cotez - O intîmplare și istorie eroicească din vremea cînd spaniolii intrară spre stäpînirea unora locuri din America prin ghenerariul Corteţ (p. $72-$ 119), the second one about Columbus - Cristof Columbus, care au aflat America întîiu, s-au născut la anul 1441 și muri la anul 1506 (p. 120-124), for which the source texts are unknown. Camară (2017, p. 27) observes that there is no relationship of affiliation between the text about Columbus in Gheografia and Descoperirea Americii, even if the same events are presented. In addition to the above, Nicolau also wrote Calendariul pe 1814, Plutarh nou (1819) - a translation containing portraits of famous people, to which he added some local figures, Invățături și îndemnuri (1830), the manuscript Mult de lipsă și folositoare invățături și științe despre mai multe lucruri (1832), containing a text translated from neo-Greek (Ursu \& Ursu, 2004, p. 398), and the manuscript Testament, written in 1793, 1796 and 1819 in Romanian and Greek and which contains a set of moral teachings.

Although the translator is not named in the text, only being mentioned that it was printed "at the expense of Nicola Nicolau from Brașov", and the afterword is signed by "a lover of the Romanian people”, Iorga (1931, p. 2) states that the merchant from Brașov would be the translator of Descoperirii Americii, because the work is characterized by "the exquisite literary form (...), the perfect calligraphy". The volume appears in 1816 at the Printing House of the University of Buda, where, at the end of the $18^{\text {th }}$ century and the beginning of the $19^{\text {th }}$ century, worked scholars who, by publishing books in Romanian (original works and translations), militated for the preservation of the Romanian identity (of the Romanian language and culture) in territories dominated by other nationalities, languages and cultures - Hungarian, Austrian, which were part of the Habsburg Empire. Between 1780 and 1830, at the Printing House of the University of Buda, approximately 240 books were printed in Romanian, most of them being secular (Tatay, 2011, p. 1).

In the afterword, Nicolau justifies the publication of the book by the fact that the Romanians did not know too much about the discovery of America: "not all the people of this nation know how, when and in

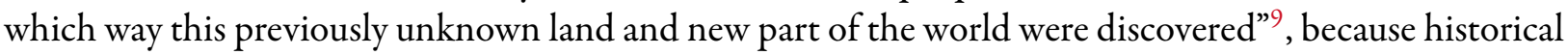
writings in Romanian were rare in those times: "Usually, such histories are not printed in Romanian." Science must be aligned with the European Enlightenment: "as well as other nations are very careful to awaken young people in these true and unexplored stories", thus affirming the historical character of the text. Finally, he summarizes volumes II and III of the series Die Endekkung von Amerika: "After his death, a lot of unknown places and countries, which were rich in gold and other natural resources, were discovered by worthy men like him. Many kinds of wars followed with the people of those places, until they could belong to other kingdoms in Europe" (p. 191-198).

From The Discovery of America by Joachim Heinrich Campe, Nicola Nicolau translates and adapts only the first 18 stories out of the 20 of the volume about Columbus, namely he does not translate stories 19 and 20, entitled Appendix for those who want to read the second part of this work, which show what happened next to the Spanish colonies founded by Columbus and what was the fate of the crew, the colonizers and Columbus' family. If the whole series of Campe's works on America is called Die Entdekkung von Amerika. Ein angenehmes und nüzliches Lesebuch für Kinder und junge Leute [The Discovery of America. A pleasant and useful book for children and youth], and the first volume is entitled Kolumbus oder die Entdekkung von Westindien [Columbus or the Discovery of West India], Nicolau only translates:

\footnotetext{
${ }^{9}$ The translation from Romanian of the fragments from Descoperirea Americii (1816) is made by the author of this article.
} 
The Discovery of America. A very useful book. He probably gave up the name of Columbus in the title, because, as he writes in the afterword, he intends to translate the entire series, if the topic will arouse the interest of the public. Unlike the German original, he omits to mention the target audience, because not only children and youth are targeted, despite the fact that he maintains the frame of the story, the dialogued form which, according to Campe, would facilitate understanding by young audiences. Finally, he gave up the adjective angenehmes Lesebuch [pleasant book], emphasizing only the usefulness of reading. Also, the author's preface is not translated. Instead of the children from the German original (Nikolas, Gottlieb, Kristel, Konrad, John, Hans, Johannes, Diederich, Peter, Ferdinand, Mathias, Karl, Fritz, Lotte), including the girls Lotte and Kristel, the father addresses three boys with Romanian names, Ioan, Andrei and Luca. Unlike the German version, the mother is not called to listen to the story, but it enters the scene episodically.

\section{Translation strategies}

Omissions, interpolations and calculations are strategies frequently used by Nicolau in drafting the Romanian text. The comparative translation analysis revealed that, in addition to omitting the translation of the last two stories, Nicolau also resorts to other omissions, which vary in length: from fragments of one or two pages to words or parts of a sentence. We will give just a few examples below. The translator leaves out some dialogues from the source text, for example when the German terms kreuzen and entern are discussed in the frame (p. 2-3), because he simplifies the text, choosing not to render the meaning of these specialized words (designating navigation terms), but only to relate the events (p. 5-6). From the fourth story he does not translate the first part, namely a geography lesson, in which the coordinates of the globe are explained. Shorter omissions can be observed in the examples below. The 1782 edition, published in Tübingen, was used as a reference for the German version.

\begin{tabular}{|c|c|c|}
\hline Source text & Romanian translation & Observations \\
\hline $\begin{array}{l}\text { In kurzer Zeit hatt' er so viel davon gefaßt, daß er nun } \\
\text { zu den Wissenschaften selbst geführet werden konte. } \\
\text { Und da hättet ihr sehen sollen, wie gierig er jedes Wort } \\
\text { verschlang, das aus dem Munde seiner Lehrer fiel! In } \\
\text { kurzer Zeit hat er in der Erdbeschreibung, Meßkunst, } \\
\text { Astronomie und im Zeichen so erstaunliche Schritte } \\
\text { gethan ... (p. 7) }\end{array}$ & $\begin{array}{l}\text { Și în scurtă vreme așa mult învăță, cît } \\
\text { putea să pășească spre învățăturile } \\
\text { cele mai mari. În scurtă vreme în } \\
\text { științele geografiei, astronomiei, și a } \\
\text { însămnării, adecă a însămna pre scris } \\
\text { ori ce lucru va vedea, atîta să } \\
\text { deșteptase... (p. 4) }\end{array}$ & \\
\hline $\begin{array}{l}\text { Nach einer Reise in den nördlichen Ozean, auf der } \\
\text { seine Einsichten ungemein erweitert wurden, trat er in } \\
\text { die Dienste eines seiner Anverwandten, eines } \\
\text { Seekapitains, der auf seine eigene Kosten einige Schiffe } \\
\text { ausgerüstet hatte... (p. 9) }\end{array}$ & $\begin{array}{l}\text { Un căpitan de corăbii, cu care el se } \\
\text { rudi, avea ale sale însuși corăbii, supt } \\
\text { acărui slujbă intră și el... (p. 5) }\end{array}$ & \\
\hline $\begin{array}{l}\text { Dieses Aus- und Einladen, und dieses Fortbringen zu } \\
\text { Lande vom rothen Meere bis nach Alexandrien, } \\
\text { erschwerten nun den Handel nach Ostindien gar sehr } \\
\text { (p. 15) }\end{array}$ & $\begin{array}{l}\text { Această încărcătură și descărcătură, și } \\
\text { asemenea greutăți, foarte tare } \\
\text { îngreuea neguțătoria la Ost-India. } \\
\text { (p. 9) }\end{array}$ & \\
\hline $\begin{array}{l}\text { Mutter. Nahm er denn seine Frau nicht mit auf diesen } \\
\text { Reisen? } \\
\text { Vater. Ich glaube, nein! Weil keiner seiner Geschichts- } \\
\text { schreiber dieses Umstandes erwähnt hat. } \\
\text { Lotte. O Mutter, nun machst du es wieder eben so, wie } \\
\text { bei der Robinsonsgeschichte! Wenn man meint, daß es } \\
\text { eben recht angehen sol: so rufst du uns immer ab. } \\
\text { Gottlieb. O laß nur, Lotte! Das thut ja Mutter nur, um } \\
\text { uns in der Enthaltsamkeit zu üben: weist du nicht? } \\
\text { Lotte. Ja, aber - } \\
\text { Alle. Zur Arbeit! Zur Arbeit! Zur Arbeit! (p. 16) }\end{array}$ & $\begin{array}{l}\text { Acestea povestind lor, intră mama lor } \\
\text { în casă, și le zise: acum ca ajungăvă a } \\
\text { povesti, veniți și la alt lucru. Și Tatăl } \\
\text { încă încetă de astă dată a mai spune } \\
\text { lor. (p. 10) }\end{array}$ & $\begin{array}{l}\text { He doesn't translate the } \\
\text { wife's question, curious } \\
\text { if Columbus was } \\
\text { accompanied by his } \\
\text { wife. The reference to } \\
\text { Robinson is also } \\
\text { omitted. }\end{array}$ \\
\hline
\end{tabular}


Omissions often require the rewriting and simplification by the Romanian translator:

\section{Source text}

Er war beherzt und munter; liebte nicht die träge Ruhe und weibliche Gemächlichkeit; verschmähte frühzeitig alle Lekkereien, die zwar den Gaum kizeln, aber auch die Gesundheit schwächen: er war ein Feind von Müßiggehn und von allen läppischen Doffen, die auf gar nichts Nützliches abzielen. (p. 7) Indem er bald die Kanarischen Inseln, bald die Küste von Afrika, und bald die Azoren besuchte. (p. 15)
Romanian translation

nu iubea lenevirea și odihna, nici mîncări, care îndulcea numai gîtul său, și sănătatea strica, fiind duşman lucrărișor zadarnice și fără de folos. (p. 4)

cînd ostrovile Canaricești, cînd țărmurile Africei, și alte, cerceta. (p. 10)

\section{Observations}

Shortens the text, giving up a series of adjectives, used in the original in some expressions.

Chooses to omit the
mention of the Azores,
from the original,
which is replaced with
others.
others.

Rarely can we identify additions / interpolations, when the translator wants to make the text easier to read:

Source text

Vor ungefähr 300 Jahren lebte zu Genua in Italien ein Mann (p. 6)

\section{Romanian translation}

Sînt peste 300 de ani, de cînd în Italia, la cetatea Genova trăia un om (p. 3)

Von seiner Herkunft weiß man nicht viel mehr, als, daß seine Voreltern sich von der Schiffarth nährten. Das war denn auch wohl die Ursache, warum auch er, von früher Jugend an, eine große Neigung zu dem Seewesen äußerte, und sich endlich diesem Stande wirklich widmete. (p. 6) cît strămoșii lui se hrănea cu călătorii spre mare, și tatăl acestui Columbus era locrătoriu de mătasă, după cum spun alți istorici. Dară el mai mult se aplecă spre meșteșugul strămoșesc,
De neamul său mai mult nu se știe, de adecă a călători spre mare, de cît a fi meșter. Aceasta trebue să fi fost și pricina, de a se da și însuși cu totul spre călătoria mării. (p. 3-4)

\begin{tabular}{lll}
\hline gute Hofnung (p. 11) & Bona Speranza, Bunei Nădejde (p. 9) & $\begin{array}{l}\text { Adds also the Spanish } \\
\text { name. }\end{array}$ \\
\hline $\begin{array}{ll}\text { Er ermunterte ihn, ein so großes Projekt doch, je eher, } \\
\text { je lieber, zur Ausführung zu bringen. (p. 20) }\end{array}$ & $\begin{array}{l}\text { îndămnînd pre dînsul cît mai îngrab, } \\
\text { atît mai bine, în săvărșire să aducă, } \\
\text { acele necunoscute țări ale căuta. } \\
\text { (p. 13) }\end{array}$
\end{tabular}

\section{Observations}

Assumption that the

Romanian reader has

less knowledge about Genoa.

Because additional information is introduced, the paragraph has to be rewritten.

Nicolau proves to be a skilled translator, who knows how to adapt the shortened text, but there are some mistakes / deviations in some places:

\section{Source text}

Er verheiratete sich nemlich, und zwar mit der Tochter eines Seekapitains, welcher einer der ersten Entdekker der Inseln Porto Santo und Madeira gewesen war. (p. 15) Dennoch vergaß er nicht, daß Irren menschlich sei (p. 19)
Romanian translation

El se căsători, și luă pre fata unui căpitan de mare, care era acel din tîiu aflătoriu Ostrovilor Porto-Santo, și Madeira. (p. 10)

Cu toate acestea, uită el, că a greși e slăbiciune omenească (p. 12)

\section{Observations}

Correct: "unul dintre cei dintîi...”.

He omits the translation of no, which changes the meaning of the sentence.

Other strategies can be observed, which are specific to the translations of those times: equivalences / calques: Ruder (p. 9) - rudă (p. 4); Hauptstadt (p. 10) - căpetenia cetate (p. 7); Ostindien (p. 11) - OstIndia (p. 7); Südpol (p. 13) - Sidpol (p. 8); Aus-und Einladen (p. 15) - incărcătură și descărcătură (p. 9); bekam in die Hände (p. 15) - intrară în mînile lui (p. 10); and glosses introduced as footnotes: Drei 
Viertel einer deutschen Meile (p. 9) - Trei fărtale de un mil nemțesc ( ${ }^{*}$ Un grad, care 15 miluri geograficeşti sau nemțesti ține, se socotește 20 miluri de mare.) (p. 4); der Rath von Genua (p. 20) - Magistratul Genovii (*divanul) (p. 14).

\section{Conclusions}

The strategies exemplified briefly are used by Nicolau for the purposes stated in the afterword, of producing the text in Romanian:

- easier transmission of historical and geographical information, by omitting those data that seem unnecessary and would make the text more difficult to read, or, conversely, by interpolations that provide additional data to a reader less accustomed with historical-geographical texts, such as the Romanian reader of those times;

- the faithful translation of moral teachings - an element specific of Enlightenment didactic works, transmitted in the form of dialogue between the father and his children, though which are analysed the behaviour and reactions, actions of the characters, who constitute models or anti-models for the young reader;

- enrichment of the Romanian language, by introducing calques and glosses and thus a specialized language.

The purpose of one of the first youth novels, Die Endekkung von Amerika, is the spreading of ideas of Enlightenment: moral education, including the spread of tolerance (towards Native Americans), and the illumination of the masses, through the transmission of historical and geographic knowledge. This goal is also achieved through versions in other European languages: the historical data interpreted in the spirit of the Enlightenment by the Scottish historian William Robertson, rewritten in the pedagogical enlightened style by the German writer Joachim Heinrich Campe, are introduced into the receiving cultures, by adding the idea of cultivating the national language and identity. In the Romanian text, the dialogued form, an element specific for the Enlightenment didactic works, is maintained, but adapted to the receiving context, by renaming the characters with Romanian names. The purpose of cultivating the Romanian language is evident from the cover page, where the Romanian translator, Nicola Nicolau, presents himself as "a lover of the Romanian people", who publishes "at all costs" this book in Romanian, from the afterword, as well as from the unfaithful translation and translation strategies.

\section{Bibliography}

Agori, M. (2005). A Marginal(ized) Perspective on Translation History: Women and Translation in the Eighteenth Century, in "Meta. Journal des traducteurs", 50 (3), p. 817-830, Crossref.

Blamires, D. (2009). Telling Tales. The Impact of Germany on English Children's Books 1780-1918, Open Book Publishers, Cambridge.

Bordaș, L. (2006). Imaginea Indiei în primele cărți de istorie și geografie tipărite în românește, in Bogdan, A. (ed.), In honorem Gabriel Ștrempel, Ed. Muzeului Sătmărean, Satu-Mare, p. 78-97.

Camară, I. (2017). Izvoare: traducerile și cursele lor, in Gînsac, 2017, p. 15-60.

Campe, J.H. (1782). Kolumbus oder die Entdekkung von Westindien. Ein angenehmes und nützliches Lesebuch für Kinder und junge Leute, Frank und Schramm, Tübingen.

Campe, J.H. (1816). Descoperirea Americii, traducere în română de Nicolau, N., Tipografia Universității din Buda, Buda.

Chindriș, I. et al. (2016). Cartea românescă veche în Imperiul Habsburgic (1691-1830). Recuperarea unei identități culturale, Mega, Cluj-Napoca.

Delisle, J. \& Woodsworth, J. (eds) (1995). Translators through History, John Benjamins, Amsterdam, Crossref.

Dietz, F. (2019). Mediated education in early modern travel stories: How travel stories contribute to children's empirical learning, in "Science in Context", 32 (2), p. 193-212, Crossref.

Even-Zohar, I. (1990). Laws of Literary Interference, in "Polysystem Studies. Poetics Today”, 11 (1), p. 53-72, Crossref.

Gheție, I. (1982). Introducere în studiul limbii române literare, Editura Științifică și Enciclopedică, București.

Gînsac, A.M. (coord.) (2017). Practici de traducere a numelor proprii în scrisul românesc premodern (1780-1830), Editura Universității “Alexandru Ioan Cuza”, Iași. 
Iorga, N. (1931). Testamentul lui Nicola Nicolau, in “Memoriile Secțiunii Istorice”, seria III, tomul XII, mem. 7, Academia Română, p. 75-87.

Mureșianu, A. (1931). Contribuție la istoria vechei familieii brașovene a Nicolaeștilor, in “Țara Bârsei”, III (4), p. $314-334$.

Neculau, N. (1814). Gheografia sau Scrierea Pământului, întocmită după orînduiala cea mai noao, aşezată pentru 4 părți ale Pămîntului, adecă: Europa, Asia, Africa, America cu tot cuprinsul lor, Tipografia Universității din Buda.

Petroff, F. (2017). William Robertson's Unfinished History of America. The Foundation of the British Empire in North America and the Scottish Enlightenment, in "Transatlantica. American Studies Journal”, 2, p. 1-17, Crossref.

Polioudakis, G. (2008). Die Übersetzung deutscher Literatur ins Neugriechische vor der Griechischen Revolution von 1821, Peter Lang, Frankfurt am Main.

Pop, E. (1946). „Societatea filosofească...” din 1795, in “Transilvania”, 77 (1-4), p. 1-15.

Shavit, Z. (1993). Literarische Beziehungen zwischen den deutschen und der jüdisch-hebräischen Kinderliteratur in der Epoche der Aufklärung am Beispielvon J. H. Campe, in Frank, A.P. et al. (eds), Übersetzen, verstehen, Brücken bauen. Geisteswissenschaftliches und literarisches Übersetzen im internationalen Kulturaustausch, vol. II, Erich Schmidt Verlag, Berlin, p. 755-765, [online].

Shavit, Z. (1995). Intercultural Relationships. The Importance of the Study of Cultural Interference for the Historical Study of Children's Literature. Test Case: The Relations Between German and Jewish Children's Literatures During the 18th and 19th Centuries, in "Compar(a)ison", 2, p. 67-80, [online].

Tatay, A.E. (2011). Gravurile în metal din cartea lui I. H. Kampe, Descoperirea Americii, Buda, 1816, in "Libraria. Studii și cercetări de bibliologie”, X, p. 176-187.

Ursu, N. A. \& Ursu, D. (2004). Imprumutul lexical în procesul modernizării limbii române literare (1760-1860), vol. I, Cronica, Iași.

Vermeer, H.J. (1978). Ein Rahmen für eine allgemeine Translationstheorie, in “Lebende Sprachen”, 23 (3), p. 99-102, Crossref.

Völpel, A. \& Shavit, Z. (2002). Deutsch-jüdische Kinder-und Jugendliteratur. Ein literaturgeschichtlicher Grundriß, J. B. Metzler, Stuttgart/Weimar.

Werner, M. \& Zimmermann, B. (2006). Beyond Comparison: Histoire Croisée and the Challenge of Reflexivity, in "History and Theory”, 45 (1), p. 30-50, Crossref. 